\title{
Classification of Austrian Rhizobia and the Mexican Isolate FL27 Obtained from Phaseolus vulgaris L. as Rhizobium gallicum
}

\author{
ANGELA SESSITSCH, ${ }^{1 *}$ HUGO RAMÍREZ-SAAD, ${ }^{2,3}$ GUDNI HARDARSON, ${ }^{1}$ \\ ANTOON D. L. AKKERMANS, ${ }^{2}$ AND WILLEM M. DE VOS $^{2}$ \\ Soil Science Unit, FAO/LAEA Agriculture and Biotechnology Laboratory, Agency's Laboratories, A-2444 Seibersdorf, \\ Austria ${ }^{1}$; Department of Microbiology, Wageningen Agricultural University, 6703 CT Wageningen, The Netherlands ${ }^{2}$; \\ and Departamento de Sistemas Biológicos, Universidad Autónoma Metropolitana-Xochimilco,
} Xochimilco, 04960 México D.F., Mexico ${ }^{3}$

\begin{abstract}
The phylogenetic positions of four rhizobial strains obtained from nodules of common bean plants (Phaseolus vulgaris L.) grown in an Austrian soil and of the Mexican bean isolate FL27 are described. Analysis of the $16 \mathrm{~S}$ rRNA genes revealed sequences almost identical to that of the Rhizobium gallicum type strain, R602sp, with a maximum of two nucleotide substitutions. Comparison of the 16S rRNA gene sequences with those from other bacteria indicated highest similarity to Rhizobium sp. strain OK-50, Rhizobium leguminosarum IAM 12609, and Rhizobium etli. DNA homology determined by DNA-DNA hybridization was high among the Austrian isolates and $\mathrm{R602sp}^{\mathrm{T}}$ (45 to 90\%) and ranged from 21 to $65 \%$ with FL27, but hybridization analysis revealed very low homology to the recognized common bean-nodulating species, $R$. leguminosarum bv. phaseoli, $R$. etli, and Rhizobium tropici. Ribosomal gene organization was studied by Southern hybridization with the 16S rRNA gene and temperature gradient gel electrophoresis, indicating identical organizations and the presence of three identical 16S rRNA copies in the genome of this species. The six strains investigated showed different plasmid profiles based on their geographical origins. We propose that the Austrian isolates and the Mexican strain FL27 are members of the species $R$. gallicum.
\end{abstract}

Bacteria of the genus Rhizobium that are able to nodulate common bean plants (Phaseolus vulgaris L.) have been traditionally classified as Rhizobium leguminosarum bv. phaseoli (13) on the basis of the host plant they infect. Strains belonging to the other subdivisions of this species, $R$. leguminosarum bv. viciae and bv. trifolii, nodulate peas and clovers, respectively, and their symbiotic plasmids carry genes with different host specificities. Nevertheless, rhizobia from common bean plants have been found to be phylogenetically diverse based on different criteria, such as protein profiles (32), multilocus enzyme electrophoresis patterns $(6,28)$, results of DNA relatedness analysis $(16,37,44)$, and differences in their 16S rRNA gene (rDNA) sequences $(9,16,44)$. In addition to $R$. leguminosarum bv. phaseoli, two new species, Rhizobium etli (38) and Rhizobium tropici (20), have been described. Both $R$. leguminosarum bv. phaseoli and $R$. etli carry multiple copies of the nitrogenase reductase gene $($ nifH $)$ on their symbiotic plasmids, but they have different $16 \mathrm{~S}$ rRNA sequences $(17,30,38)$. In contrast, $R$. tropici maintains only a single nifH gene copy on its symbiotic plasmid (20). R. etli and $R$. tropici show a broad host range, but they nodulate different hosts $(9,20)$. Several new species among bean-nodulating strains, including Rhizobium gallicum and Rhizobium giardinii, which comprise the French isolates (1, 16), as well as Rhizobium sp. (Phaseolus) RCR 3618D of unknown geographical origin, have been proposed (44). The partial 16S rDNA sequence of the $R$. gallicum type strain, R602sp, was found to be identical to that of strain FL27 (16), a Mexican isolate from the common bean which does not fixate $\mathrm{N}_{2}$ well (28). In general, strains of Rhizobium that nodulate bean plants are of American origin, as is their host plant. For a long time it was believed that in Europe, $R$. leguminosarum bv. phaseoli

\footnotetext{
${ }^{*}$ Corresponding author. Present address: Department of Microbiology, Wageningen Agricultural University, 6703 CT Wageningen, The Netherlands. Phone: 31317 484250. Fax: 31317483829 . E-mail: angela .sessitsch@algemeen.micr.wau.nl.
}

was the only microsymbiont of common bean plants, but recently several species, including $R$. etli, $R$. tropici, $R$. gallicum, and $R$. giardinii, were found in European soils $(1,2,16,41)$.

Rhizobial strains recovered from common bean nodules from an Austrian soil showed high similarity to $R$. gallicum R602 $\mathrm{sp}^{\mathrm{T}}$ by PCR analysis with repetitive primers and PCRrestriction fragment length polymorphism (RFLP) analysis of the 16S rRNA gene (41). In addition, the nifH profiles and the nodulation phenotypes were identical (41). The aim of this study was to confirm that the Austrian isolates are members of the recently described species $R$. gallicum. As the Mexican isolate FL27 exhibited several similarities to $R$. gallicum, it was included in this investigation. Phylogenetic analysis was done by phenotypical characterization as well as sequence analysis of the 16S rRNA gene, analysis of the copy numbers and heterogeneity of ribosomal genes, analysis of plasmid profiles, and DNA-DNA hybridization.

\section{MATERIALS AND METHODS}

Bacterial strains, phenotypic characterization, and nodulation host range. Four strains, CbS- 1 , CbS-3, CbS-17, and CbS-18, were isolated from common bean plants grown in soil from fields around the Seibersdorf laboratory in Austria and characterized previously (41). $R$. gallicum R602 $\mathrm{sp}^{\mathrm{T}}$, the Mexican isolate FL27, and reference strains were obtained either from G. Laguerre, Dijon, France, or from the culture collection at the Seibersdorf laboratory. All rhizobial strains were maintained on yeast extract-mannitol (YM) medium (46), and FL27, R602sp ${ }^{\mathrm{T}}$, CbS-1, CbS-3, CbS-17, and CbS-18 were tested for growth on LuriaBertani medium (21) and on peptone-yeast extract medium (22). In order to test substrate utilization, modified minimal B\&D medium (48) was amended with the following carbon sources at a concentration of $1 \mathrm{~g} /$ liter: D-glucose, starch, maltose, urea, fructose, D-lactose, D-sorbitol, D-xylose, D-mannose, arabinose, Dribose, myoinositol, melobiose, raffinose, D-trehalose, methanol, and ethanol. The amino acids L-alanine, L-aspartic acid, L-asparagine, L-arginine, L-cysteine, L-glutamate, L-glutamine, L-histidine, L-leucine, L-methionine, L-phenylalanine, L-proline, L-serine, L-tryptophan, L-threonine, L-tyrosine, and L-valine were each tested as a sole carbon and nitrogen source at a concentration of $1 \mathrm{~g} /$ liter. Resistance to antibiotics was tested by plating the rhizobial strains on YM agar medium containing ampicillin $(10 \mu \mathrm{g} / \mathrm{ml})$, chloramphenicol $(30 \mu \mathrm{g} / \mathrm{ml})$, kanamycin $(30 \mu \mathrm{g} / \mathrm{ml})$, tetracycline $(10 \mu \mathrm{g} / \mathrm{ml})$, nalidixic acid $(10 \mu \mathrm{g} / \mathrm{ml})$, spectinomycin $(100 \mu \mathrm{g} / \mathrm{ml})$, or streptomycin $(100 \mu \mathrm{g} / \mathrm{ml})$.

Growth at different temperatures $\left(20,25,30,35,37\right.$, and $\left.40^{\circ} \mathrm{C}\right)$, growth on YM 
medium containing different concentrations of $\mathrm{NaCl}(1.0,1.5$, and $2 \% \mathrm{NaCl})$, and growth at different $\mathrm{pH}$ values ( $\mathrm{pHs} 4,5,6,7,8,9$, and 10) were determined in liquid culture.

The nodulation host range of FL27 was determined as described previously (41) with Phaseolus vulgaris cv. Extender, Vicia faba cv. Weiselburger, Pisum sativum cv. Rheinperle, Trifolium repens $\mathrm{cv}$. Reichersberger, Medicago sativa $\mathrm{cv}$. Saranac, Glycine max cv. Clay, Vigna unguiculata cv. Red Caloona, Leucaena leucocephala cv. Cunningham, Glinicidia sepium, and Acacia albida.

Plasmid profiles, DNA isolation, and rDNA hybridization. Plasmid profiles of $\mathrm{CbS}-1, \mathrm{CbS}-3, \mathrm{CbS}-17, \mathrm{CbS}-18, \mathrm{R} 602 \mathrm{sp}^{\mathrm{T}}$, FL27, and CIAT $899^{\mathrm{T}}$ were investigated as described by Hynes et al. (12). Total genomic DNA was prepared as described elsewhere (3) with omission of the $\mathrm{CsCl}$ purification step. Genomic DNA was digested with HindIII, and the resulting fragments were separated by electrophoresis with a $0.7 \%$ agarose gel that was blotted onto a Hybond-N membrane (Amersham International, Little Chalfont, Buckinghamshire, United Kingdom). A probe containing the $16 \mathrm{~S}$ rRNA gene from strain R602sp ${ }^{\mathrm{T}}$ was prepared by PCR with the primers rD1 and fD1 (47) as described previously (41). After isolation of the resulting fragment from a $1 \%$ agarose gel with a GeneClean II Kit (Bio 101, Inc., La Jolla, Calif.), it was labeled with $\left[\alpha-{ }^{32}\right.$ P]dATP by using the Multiprime DNA labeling system (Amersham International) according to the manufacturer's protocol. Hybridization was carried out at $65^{\circ} \mathrm{C}$ for $2 \mathrm{~h}$ in Rapid-Hyb buffer (Amersham International) and washing and autoradiography were done as described elsewhere (39).

DNA-DNA hybridization. Dot blot hybridizations were performed as described previously (15) with $25-\mu \mathrm{l}$ samples containing $400 \mathrm{ng}$ of genomic DNA. In addition, $400 \mathrm{ng}$ of denaturated calf thymus DNA was transferred onto the membrane. The membranes were hybridized with $4 \mu \mathrm{g}$ of genomic DNA previously digested with $A l u \mathrm{I}$ and labeled with $\left[\alpha{ }^{32} \mathrm{P}\right] \mathrm{dATP}$ by using the Multiprime DNA labeling system per dot. Hybridization was carried out under relaxed conditions at $55^{\circ} \mathrm{C}$ for $2 \mathrm{~h}$ in Rapid-Hyb buffer. The filters were washed under stringent conditions at $60^{\circ} \mathrm{C}$ in a solution containing $0.03 \mathrm{M} \mathrm{NaCl}, 0.003 \mathrm{M}$ sodium citrate, and $1 \%$ sodium dodecyl sulfate. Membranes were cut, and 9 - by 9-mm pieces were counted with a liquid scintillation counter (Tri Carb 2200CA Packard). The amount of radioactivity associated with calf thymus DNA was subtracted, and the percentages of DNA relatedness were determined relative to the signal found in the homologous hybridization.

Analysis of the 16S rRNA genes. The $16 \mathrm{~S}$ rRNA genes of CbS-1, CbS-3, $\mathrm{CbS}-17$, CbS-18, and R602sp ${ }^{\mathrm{T}}$ were amplified by using the primers FGPS6-63 (with a Bg/II site) (16) and P1510Pst (with a PstI site) (23) and a standard protocol (41). The amplified fragments were digested with Bg/II and PstI and then cloned into pUC18Not that had been previously cut with BamHI and PstI. As the 16S rRNA gene of strain FL27 showed an internal PstI restriction site, the gene was amplified by using the primers FGPS6-63 (16) and P1510HIII equipped with a HindIII site (5'-GTGAAGCTTGGTTACCTTGTTACGACT-3'), where the HindIII site is italicized. The resulting fragment was digested with BglII and HindIII and then cloned into BglI- and HindIII-cut pUC18Not, with Escherichia coli DH5 $\alpha$ as the recipient. DNA sequence analysis of the cloned 16S rRNA gene fragments was done by using the dideoxy-chain termination method (35) with a model LI-COR 4000L automated sequencer.

For the temperature gradient gel electrophoresis (TGGE), total genomic DNA was used as the template to amplify a fragment of ca. $440 \mathrm{bp}$ comprising the V6 to V8 variable region of the 16S rRNA gene. The primers used, PCR and TGGE, were previously described by Nübel et al. (24).

Sequence alignment and phylogenetic analysis. Gene banks were searched by using the FASTA tool (27), and alignments of selected 16S rDNA sequences were done with the ClustalW multiple-alignment program (10). Short regions of uncertain alignment were excluded from further analyses. Calculation of evolutionary distances was done with the Jukes and Cantor model (14). Phylogenetic trees based on the neighbor-joining method (34) were constructed with 100 bootstrap replicates by using the TREECON for Windows software package (45). A maximum parsimony phylogenetic tree was created with the program PAUP3.1 (43).

Nucleotide sequence accession numbers. The 16S rRNA gene sequences of the strains analyzed have been deposited in GenBank under the accession no. AF008126 (CbS-1), AF008127 (CbS-17), AF008128 (CbS-29), AF008129 (FL27), and $\mathrm{AF} 008130\left(\mathrm{R} 602 \mathrm{sp}^{\mathrm{T}}\right)$.

\section{RESULTS}

Phenotypic characterization. The strains CbS-1, CbS-3, CbS-17, CbS-18, R602sp ${ }^{\mathrm{T}}$, and FL27 showed identical characteristics. They could not utilize the following compounds: starch, urea, methanol, ethanol, L-alanine, L-arginine, L-asparagine, L-cysteine, L-phenylalanine, and L-tryptophan. The strains were not able to grow on Luria-Bertani medium or on YM medium supplemented with high (above 1\%) concentrations of $\mathrm{NaCl}$, but they could be cultivated on peptone-yeast extract medium. All strains were able to grow on D-glucose, maltose, fructose, D-lactose, D-sorbitol, D-xylose, D-mannose,

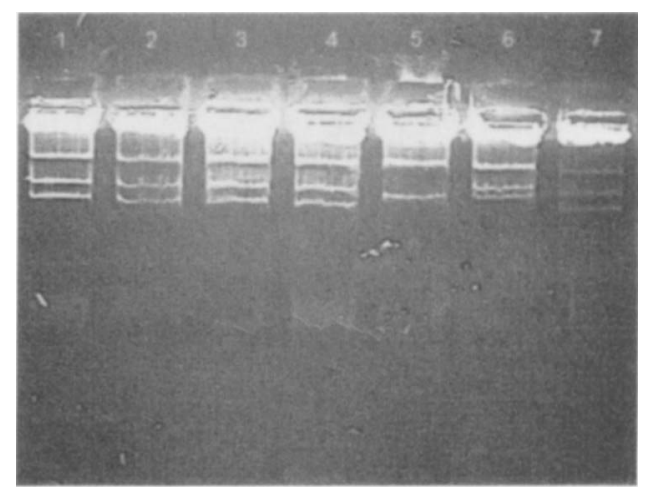

FIG. 1. Plasmid profiles of CbS-1 (lane 1), CbS-3 (lane 2), CbS-17 (lane 3), CbS-18 (lane 4), R602sp ${ }^{\mathrm{T}}$ (lane 5), FL27 (lane 6), and CIAT $899^{\mathrm{T}}$ (lane 7).

arabinose, D-ribose, myoinositol, melibiose, raffinose, D-trehalose, L-aspartic acid, L-glutamate, L-glutamine, L-histidine, Lleucine, L-methionine, L-proline, L-serine, L-threonine, L-tyrosine, and L-valine. The strains were able to grow on plates supplemented with ampicillin, chloramphenicol, and nalidixic acid. The optimum $\mathrm{pH}$ range was from 6 to 8 , while no growth occurred at pHs 4,9 , and 10 . All isolates were able to grow at a temperature up to $37^{\circ} \mathrm{C}$ but did not grow at $40^{\circ} \mathrm{C}$. Among the host plants tested, FL27 was able to nodulate common bean plants, cowpea plants, Leucaena spp., and Gliricidia spp.

Plasmid profiles. Plasmid analysis showed that the Austrian isolates $\mathrm{CbS}-1, \mathrm{CbS}-3, \mathrm{CbS}-17$, and CbS-18 carried three plasmids identical in size but that the French strain R602sp ${ }^{T}$ harbored two plasmids. Strain FL27 and $R$. tropici CIAT $899^{\mathrm{T}}$ also carried three plasmids but had patterns different from each other and from those of the Austrian isolates. The largest plasmids of the Austrian isolates and of R602sp ${ }^{\mathrm{T}}$ and FL27 appeared to have the same size (Fig. 1).

Ribosomal gene organization. Southern hybridization with the 16S rRNA gene of $\mathrm{R} 602 \mathrm{sp}^{\mathrm{T}}$ as a probe showed that isolates CbS-1, CbS-3, CbS-17, CbS-18, R602sp ${ }^{T}$, FL27, $R$. leguminosarum bv. phaseoli $\mathrm{H} 131$, and $R$. etli CFN $42^{\mathrm{T}}$ contained at least three copies of the $16 \mathrm{~S}$ rRNA gene. Both $R$. tropici CIAT $899^{\mathrm{T}}$ and $R$. tropici CFN $299^{\mathrm{T}}$ carried one copy of the $16 \mathrm{~S}$ rRNA gene. The Austrian isolates, R602sp ${ }^{T}$ and FL27 showed identical patterns with three hybridizing HindIII fragments of $4.6,11.0$, and $12.9 \mathrm{~kb}$.

TGGE analysis of PCR-amplified segments of 16S rDNAs resulted in single band profiles for each tested strain (data not shown). This result suggested that the sequences in those strains bearing more than one copy of the gene are identical.

DNA-DNA hybridization. Isolates CbS-1, CbS-3, CbS-17, CbS-18, and R602sp ${ }^{\mathrm{T}}$ showed high levels of DNA relatedness ranging from 45 to $90 \%$. Homologies among the European isolates and FL27 ranged from 52 to $65 \%$ when FL27 was used as the probe and from 21 to $40 \%$ when the same strain was used as the template (Table 1). The average values of the percentages when FL27 was used as the probe and when it was used as the template ranged from 41 to $48 \%$ (data not shown). The DNA relatedness values of the Austrian strains, R602sp ${ }^{\mathrm{T}}$, and FL27 with $R$. leguminosarum, $R$. tropici, and $R$. etli were very low (Table 1 ).

Analysis of the 16S rRNA gene sequence. The determined 16S rDNA sequences of strains CbS-1 and CbS-3 were identical and differed by only one nucleotide from those of strains CbS-18 and R602sp ${ }^{T}$. Two substitutions at different positions were found when these four sequences were compared with the sequences of strains CbS-17 and FL27. FASTA analysis 
TABLE 1. Levels of DNA relatedness between CbS-1, CbS-3, CbS-17, CbS-29, R602sp ${ }^{T}$, FL27, and other common bean-nodulating Rhizobium species

\begin{tabular}{|c|c|c|c|c|c|c|c|c|c|c|}
\hline \multirow{2}{*}{ Strain $^{a}$} & \multicolumn{10}{|c|}{$\%$ DNA relatedness with ${ }^{b}:$} \\
\hline & $\mathrm{CbS}-1$ & $\mathrm{CbS}-3$ & $\mathrm{CbS}-17$ & $\mathrm{CbS}-18$ & $\mathrm{R} 602 \mathrm{sp}^{\mathrm{T}}$ & FL27 & H131 & CIAT $899^{\mathrm{T}}$ & CFN $299^{\mathrm{T}}$ & $\mathrm{CFN} 42^{\mathrm{T}}$ \\
\hline $\mathrm{CbS}-1$ & 100 & 76 & 75 & 69 & 90 & 60 & 7 & 7 & 19 & 11 \\
\hline $\mathrm{CbS}-3$ & 83 & 100 & 80 & 87 & 83 & 65 & 7 & 5 & 13 & 12 \\
\hline $\mathrm{CbS}-17$ & 90 & 83 & 100 & 88 & 82 & 62 & 6 & 5 & 9 & 14 \\
\hline $\mathrm{CbS}-18$ & 45 & 68 & 86 & 100 & 87 & 52 & 2 & 1 & 7 & 7 \\
\hline Rhizobium sp. strain R602sp $\mathrm{sp}^{\mathrm{T}}$ & 55 & 82 & 79 & 74 & 100 & 61 & 5 & 3 & 8 & 14 \\
\hline Rhizobium sp. strain FL27 & 26 & 21 & 40 & 30 & 35 & 100 & 5 & 14 & 6 & 12 \\
\hline R. leguminosarum bv, phaseoli H131 & 6 & 4 & 3 & 4 & 11 & 5 & 100 & 6 & 12 & 22 \\
\hline R. tropici CIAT $899^{\mathrm{T}}$ & 8 & 5 & 5 & 5 & 8 & 5 & 4 & 100 & 33 & 7 \\
\hline R. tropici CFN $299^{\mathrm{T}}$ & 7 & 5 & 5 & 4 & 5 & 5 & 3 & 14 & 100 & 11 \\
\hline R. etli $\mathrm{CFN} 42^{\mathrm{T}}$ & 7 & 12 & 5 & 5 & 9 & 6 & 18 & 4 & 7 & 100 \\
\hline
\end{tabular}

\footnotetext{
${ }^{a}$ DNA used as a template.

${ }^{b}$ DNA used as a probe. DNA relatedness values of strains CbS-1, CbS-3, CbS-17, CbS-18, R602sp ${ }^{\mathrm{T}}$, and FL27 are mean values obtained from the results of two
} independent experiments.

indicated several members of the alpha subclass of Proteobacteria as having the most related $16 \mathrm{~S}$ rDNA sequences. All further comparisons were based on 1,431 nucleotides comprising more than $93 \%$ of the $16 \mathrm{~S}$ rRNA gene. Rhizobium sp. strain OK-50 (26), $R$. leguminosarum IAM 12609 (26), and $R$. etli had the highest homology values, namely, 97.9, 97.9, and $97.6 \%$, respectively. Phylogenetic dendrograms constructed by both the distance and the parsimony method showed essentially the same topology and similar evolutionary distances; the latter method yielded only one most parsimonious tree. The neighbor-joining phylogenetic tree (Fig. 2) showed a well-defined and compact cluster comprising $R$. gallicum $\mathrm{R} 602 \mathrm{sp}^{\mathrm{T}}$; the Austrian isolates CbS-1, CbS-17, and CbS-18; and the Mexican isolate FL27. This cluster was clearly separated from other well-recognized rhizobial lineages and supported by high bootstrap values.

\section{DISCUSSION}

High relatedness among common bean-nodulating strains isolated in Austria (CbS-1, CbS-3, CbS-17, and CbS-18) and the French Rhizobium strain R602sp ${ }^{\mathrm{T}}$ was demonstrated by using several approaches targeting symbiotic and chromosomal regions of the genome as well as the nodulation phenotype (41). In a recent study, strain $\mathrm{R} 602 \mathrm{sp}^{\mathrm{T}}$ as well as other isolates obtained from French soils was classified as a new species, $R$. gallicum, with R602sp as the type strain (1). The Mexican isolate FL27 and strain R602sp ${ }^{\mathrm{T}}$ showed identical partial 246-bp 16S rRNA gene sequences as well as identical PCRRFLP profiles of their $16 \mathrm{~S}$ rRNA genes (16). In the present study, sequence analysis of $93 \%$ of the $16 \mathrm{~S}$ rRNA genes revealed high homology among the four Austrian isolates, $\mathrm{R} 602 \mathrm{sp}^{\mathrm{T}}$, and FL27, with a maximum of two nucleotide substitutions. One nucleotide difference in FL27 resulted in an internal Pst I restriction site that was absent in all European isolates. Comparison of the $16 \mathrm{~S}$ rDNA sequences with those of other bacteria confirmed the findings of Amarger et al. (1), and the $16 \mathrm{~S}$ rDNA sequences showed highest similarity to Rhizobium sp. strain OK-50 isolated from Pterocarpus klemmei in Japan (26), to R. leguminosarum IAM 12609 (26), and to R. etli. This finding is in agreement with Eardly et al. (5), who reported high similarity between FL27 and $R$. etli by sequence analysis of a 260 -bp segment of their $16 \mathrm{~S}$ rRNA genes. Phylogenetic dendrograms always positioned the Austrian isolates and strain FL27 in the $R$. gallicum cluster, and $R$. gallicum was found to be a member of a lineage different from those of described Rhizobium species.

Although ribosomal gene sequences play an important role in the description of new species, in many cases there is only a limited correlation between DNA relatedness and 16S rDNA homology. This finding was reported for Rhizobium (25) but also for other bacterial genera, such as Aeromonas and Plesiomonas (18). Recently, van Berkum et al. (44) suggested that although the level of $16 \mathrm{~S}$ rDNA sequence similarity among bean rhizobia is high, the DNA relatedness data indicate different species. Stackebrandt and Goebel (42) demonstrated that the correlation between $16 \mathrm{~S}$ rDNA homology and DNADNA reassociation is not necessarily linear, indicating that distinct species can show high $16 \mathrm{~S}$ rDNA sequence similarities. Assessment of DNA relatedness was proposed as an important criterion for the description of new species of root- and stemnodulating bacteria (8). The strains tested in the present study had very low DNA homology with the recognized common bean-nodulating species, i.e., $R$. leguminosarum, $R$. tropici, and $R$. etli. This result is in agreement with the work of MartínezRomero (19), who found low DNA relatedness between $R$. etli and FL27. High DNA homology was found among the European isolates. The Mexican isolate FL27, however, had lower DNA relatedness to the European strains. It is not clear why generally higher values were obtained when a particular strain was used as a probe than when the same strain was used as a template. However, the average values of the percentages when FL27 was used as a probe and when it was used as a template in combination with the 16S rDNA similarities are within the possible range suggested by Stackebrandt and Goebel (42). One explanation for the lower DNA relatedness of FL27 to the other $R$. gallicum strains may be the presence of plasmids in FL27 showing little homology with those of the European isolates. These plasmids may carry up to $25 \%$ of the genetic information in Rhizobium (29), and plasmids are prone to losses or alterations. High-frequency plasmid-borne rearrangements, including sequence amplification, deletion, cointegration, and loss, have been particularly observed in $R$. etli $\mathrm{CFN} 42^{\mathrm{T}}$ plasmids $(4,33)$. In addition, exchange of plasmids among Rhizobium populations has been reported (31, 36). Interestingly, the Mexican, French, and Austrian strains showed plasmid profiles that reflected their geographical origins.

Data obtained by Martínez-Romero et al. (20) suggested that the RFLPs of rRNA in Rhizobium operons are species 


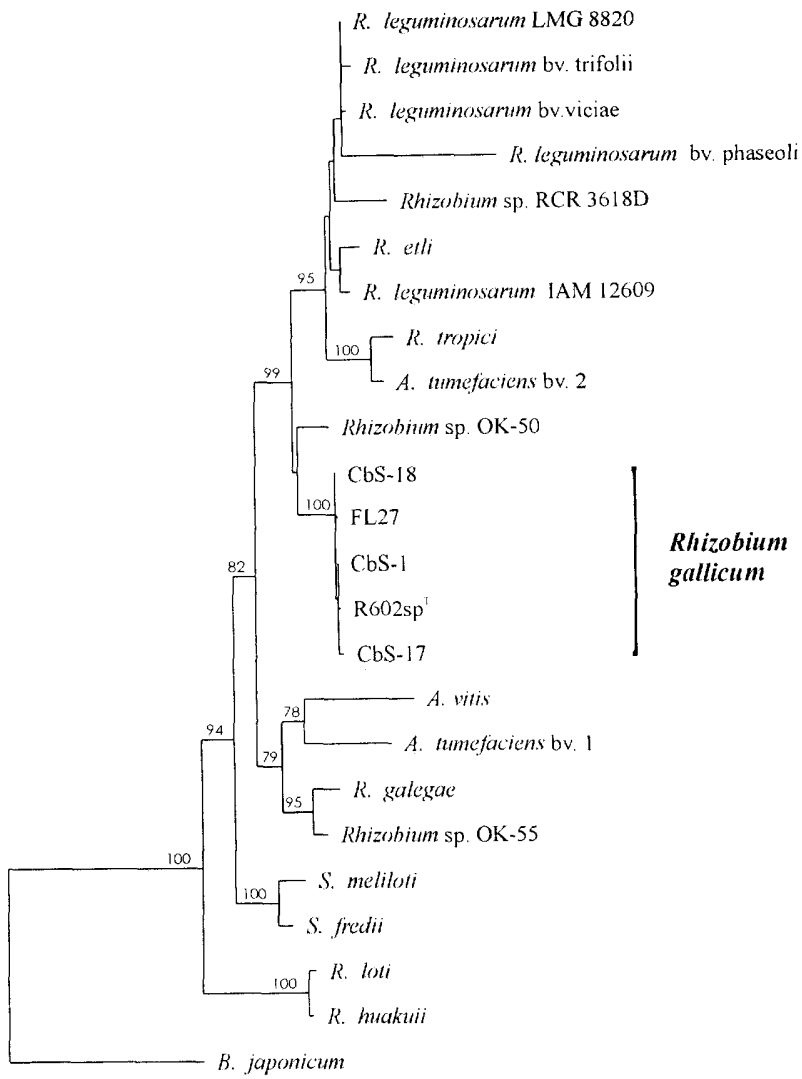

FIG. 2. Neighbor-joining phylogenetic tree based on 1,431 nucleotides of the $16 \mathrm{~S}$ rDNAs of different rhizobia and related genera. Percentages of 100 bootstrap replicates are shown when they are above $75 \%$. The $R$. gallicum cluste including R602sp ${ }^{\mathrm{T}}$, FL27, and the Austrian isolates is clearly separated from other rhizobial groups and supported by a $100 \%$ bootstrap value. Accession no. of the 16S rDNA sequences used are X67227 ( $R$. leguminosarum LMG 8820), $\mathrm{U} 31074$ ( $R$. leguminosarum bv. trifolii T24), U29386 ( $R$. leguminosarum bv. viciae ATCC 10004), U29388 ( $R$. leguminosarum bv. phaseoli RCR 3644), U29387 (Rhizobium sp. strain RCR 3618D), U28916 ( $R$. etli CFN 42 $\left.{ }^{\mathrm{T}}\right), \mathrm{D} 14513(R$ leguminosarum IAM $12609^{\mathrm{T}}$ ), U38469 (R. tropici type IIB CIAT 166), D01257 (Agrobacterium tumefaciens bv. 2 IFO 13257), D01271 (Rhizobium sp. strain OK-50), AF008126 (strain CbS-1), AF008127 (strain CbS-17), AF008128 (strain CbS-18), AF008129 (strain FL27), AF008130 ( $R$. gallicum R602sp ${ }^{\mathrm{T}}$ ), D012528 (A. vitis NCPPB 3554), D01256 (A. tumefaciens bv. 1 NCPPB 2437), D11343 ( $R$ galegae ATCC 43677), D01266 (Rhizobium sp. strain OK-55), D14509 (Sinorhizobium meliloti IAM $12611^{\mathrm{T}}$ ), D14516 (S. fredii ATCC 35423 ${ }^{\mathrm{T}}$ ), D12791 (Rhizobium loti IAM 3588), D13431 (Rhizobium huakuii IFO 15243), and D13429 (Bradyrhizobium japonicum USDA 94), which was used as an outgroup.

specific but that riboprobing based on pulsed-field gel electrophoresis fingerprints resulted in strain-specific patterns among Rhizobium galegae strains (11). The identical 16S rRNA organizations in FL27, R602 $\mathrm{sp}^{T}$, and the Austrian isolates is an additional factor indicating the close relationship of these strains. Our study as well as results obtained by Huber and Selenska-Pobell (11) suggests that the presence of three rRNA operons is common among rhizobia. Previously, Southern analysis of R602sp ${ }^{T}$ and the Austria isolates with a nifH gene fragment resulted in hybridization with a fragment of the same size, indicating the presence of one copy of the nifH gene and related nif gene organization (41). Based on differences in the symbiotic plasmid and nodulation host range, $R$. gallicum was divided in two biovars, phaseoli and gallicum, containing either three copies or a single copy of the nifH gene (1). No differ- ences in the results of phenotypic analysis were found among the Austrian strains, R602sp ${ }^{\mathrm{T}}$, and FL27, and the results correlated well with those reported by Amarger et al. (1). In a former study the Austrian strains and R602sp ${ }^{T}$ showed the same nodulation host range for nodulating not only bean plants but also cowpea plants, Leuceana, and Gliricidia (41). Although isolated from a very different geographical region, FL27 exhibited the same nodulation host range, indicating the presence of the same or a related symbiotic plasmid among the European strains and FL27.

From our analyses it is evident that the Austrian isolates are members of $R$. gallicum bv. gallicum, and we also propose that FL27 belongs to this species. As Mesoamerica, where FL27 was isolated, is one center of origin of the common bean plant (7), it is possible that $R$. gallicum has been imported to Europe as a seed contaminant. Bean rhizobia belonging to species originating in the Americas, such as $R$. tropici and $R$. etli, have been found in Europe $(2,41)$. In addition, Martínez-Romero (19) suggested that $R$. leguminosarum bv. phaseoli strains are a result of plasmid transfer in historic times because of the high similarity of their symbiotic plasmids with that from $R$. etli. The origin of $R$. giardinii, a recently described species that nodulates bean plants and that was obtained from France, is unknown (1). However, two biovars, $R$. giardinii bv. giardinii and bv. phaseoli, have been described and it was suggested that $R$. giardinii bv. phaseoli as well as $R$. gallicum bv. phaseoli received their symbiotic plasmids from $R$. leguminosarum (1). On the other hand, FL27 was isolated from bean plants grown in a Leucaena field and was demonstrated to be a poor $\mathrm{N}_{2}$ fixer in common bean nodules (28), and therefore it is uncertain whether the common bean plant is the true host of $R$. gallicum bv. gallicum. Nevertheless, the Austrian isolates possess high competitive ability in nodulating bean plants in a soil where they adapted well $(40,41)$. Further studies will be needed to understand the origin of bean plant-nodulating rhizobia in Europe as well as the role and frequency of plasmid transfer in their evolution.

\section{ACKNOWLEDGMENTS}

We are grateful to A. Felske for performing the TGGE analysis and R. Schafleitner for helping with the DNA-DNA hybridizations as well as for invaluable discussions. We thank A. Geerling and I. Heikamp-de Jong for excellent technical support in carrying out the sequencing.

H.R.-S. received a fellowship from CONACYT (Mexico).

\section{REFERENCES}

1. Amarger, N., V. Macheret, and G. Laguerre. 1997. Rhizobium gallicum $\mathrm{sp}$ nov. and Rhizobium giardinii sp. nov., from Phaseolus vulgaris nodules. Int. J. Syst. Bacteriol. 47:996-1006.

2. Amarger, N., M. Bours, F. Revoy, M.-R. Allard, and G. Laguerre. 1994. R. tropici nodulates field-grown Phaseolus vulgaris in France. Plant Soil 161: 147-156.

3. Ausubel, F. M., R. Brent, R. E. Kingston, D. D. Moore, J. G. Seidman, J. A. Smith, and K. Struhl (ed.). 1995. Current protocols in molecular biology. Wiley, New York, N.Y.

4. Brom, S., A. García de los Santos, M. de Lourdes Girard, G. Dávila, R. Palacios, and D. Romero. 1991. High-frequency rearrangements in Rhizobium leguminosarum bv. phaseoli plasmids. J. Bacteriol. 173:1344-1346.

5. Eardly, B. D., J. P. W. Young, and R. K. Selander. 1992. Phylogenetic position of Rhizobium sp. strain Or 191, a symbiont of both Medicago sativa and Phaseolus vulgaris, based on partial sequences of the 16S rRNA and nifH genes. Appl. Environ. Microbiol. 58:1809-1815.

6. Eardly, B. D., F.-S. Wang, T. S. Whittam, and R. K. Selander. 1995. Species limits in Rhizobium populations that nodulate the common bean (Phaseolus vulgaris). Appl. Environ. Microbiol. 61:507-512.

7. Gebts, P. 1990. Biochemical evidence bearing on the domestication of Phaseolus (Fabaceae) beans. Econ. Bot. 44:28-38.

8. Graham, P. H., M. J. Sadowsky, H. H. Keyser, Y. M. Barnet, R. S. Bradley, J. E. Cooper, D. J. de Ley, B. D. W. Jarvis, E. B. Roslycky, B. W. Strijdom, and J. P. W. Young. 1991. Proposed minimal standards for the description of new genera and species of root- and stem-nodulating bacteria. Int. J. Syst. Bacteriol. 41:582-587. 
9. Hernandez-Lucas, I., L. Segovia, E. Martínez-Romero, and S. G. Pueppke. 1995. Phylogenetic relationships and host range of Rhizobium spp. that nodulate Phaseolus vulgaris L. Appl. Environ. Microbiol. 61:2775-2779.

10. Higgins, D. G., A. J. Bleasby, and R. Fuchs. 1992. CLUSTAL V: improved software for multiple sequence alignment. Comput. Appl. Biosci. 8:189-191.

11. Huber, I., and S. Selenska-Pobell. 1994. Pulsed-field gel electrophoresisfingerprinting, genome size estimation and rrn loci number of Rhizobium galegae. J. Appl. Bacteriol. 77:528-533.

12. Hynes, M. F., R. Simon, and A. Pühler. 1985. The development of plasmidfree strains of Agrobacterium tumefaciens by using incompatibility with a Rhizobium meliloti plasmid to eliminate pAtC58. Plasmid 13:99-105.

13. Jordan, D. C. 1984. Family III. Rhizobiaceae, p. 235-242. In N. R. Krieg and J. G. Holt (ed.), Bergey's manual of systematic bacteriology, vol. 1. Williams \& Wilkins, Baltimore, Md.

14. Jukes, T. H., and C. R. Cantor. 1969. Evolution of protein molecules, p. 21-132. In H. N. Munro (ed.), Mammalian protein metabolism. Academic Press, New York, N.Y.

15. Klijn, N., C. Bovie, J. Dommes, J. D. Hoolwerf, C. B. van der Waals, A. H. Weerkamp, and F. F. J. Nieuwenhof. 1994. Identification of Clostridium tyrobutyricum and related species using sugar fermentation, organic acid formation and DNA probes based on specific 16S rRNA sequences. Syst. Appl. Microbiol. 17:249-256.

16. Laguerre, G., M. P. Fernandez, V. Edel, P. Normand, and N. Amarger. 1993. Genomic heterogeneity among French Rhizobium strains isolated from Phaseolus vulgaris L. Int. J. Syst. Bacteriol. 43:761-767.

17. Martínez, E., M. A. Pardo, R. Palacios, and M. A. Cevallos. 1985. Reiteration of nitrogen fixation gene sequences and specificity to Rhizobium in nodulation and nitrogen fixation in Phaseolus vulgaris. J. Gen. Microbiol. 131:1779-1786.

18. Martínez-Murcia, A. J., S. Benlloch, and M. D. Collins. 1992. Phylogenetic interrelationships of members of the genera Aeromonas and Plesiomonas as determined by $16 \mathrm{~S}$ ribosomal DNA sequencing: lack of congruence with results of DNA-DNA hybridizations. Int. J. Syst. Bacteriol. 42:412-421.

19. Martínez-Romero, E. 1994. Recent developments in Rhizobium taxonomy. Plant Soil 161:11-20.

20. Martínez-Romero, E., L. Segovia, F. M. Mercante, A. A. Franco, P. Graham, and M. A. Pardo. 1991. Rhizobium tropici, a novel species nodulating Phaseolus vulgaris L. beans and Leucaena sp. trees. Int. J. Syst. Bacteriol. 41:417426.

21. Miller, J. H. 1972. Experiments in gene fusions. Cold Spring Harbor Laboratory, Cold Spring Harbor, N.Y

22. Noel, K. D., F. Sánchez, L. Fernández, J. Leemans, and M. A. Cevallos. 1984. Rhizobium phaseoli symbiotic mutants with transposon $\operatorname{Tn} 5$ insertions. J. Bacteriol. 158:148-155.

23. Nölling, J., D. Hahn, W. Ludwig, and W. M. de Vos. 1993. Phylogenetic analysis of thermophilic Methanobacterium sp.: evidence for a common formate-utilizing ancestor. Syst. Appl. Microbiol. 16:208-215.

24. Nübel, U., B. Engelen, A. Felske, J. Snaidr, A. Wieshuber, R. I. Amann, W. Ludwig, and H. Backhaus. 1996. Sequence heterogeneities of genes encoding 16S rRNAs in Paenibacillus polymyxa detected by temperature gradient gel electrophoresis. J. Bacteriol. 178:5636-5643.

25. Oyaizu, H., N. Naruhashi, and T. Gamou. 1992. Molecular methods of analysing bacterial diversity: the case of rhizobia. Biodivers. Conserv. 1:237249.

26. Oyaizu, H., S. Matsumoto, K. Minamisawa, and T. Gamou. 1993. Distribution of rhizobia in leguminous plants surveyed by phylogenetic identification. J. Gen. Appl. Microbiol. 39:339-354.

27. Pearson, W. R., and D. J. Lipman. 1988. Improved tools for biological sequence comparison. Proc. Natl. Acad. Sci. USA 82:2444-2448.

28. Piñero, D., E. Martínez, and R. K. Selander. 1988. Genetic diversity and relationships among isolates of Rhizobium leguminosarum biovar phaseoli. Appl. Environ. Microbiol. 54:2825-2832.

29. Prakash, R. K., and A. G. Atherly. 1986. Plasmids of Rhizobium and their role in symbiotic nitrogen fixation. Int. Rev. Cytol. 104:1-24.

30. Quinto, C., H. de la Vega, M. Flores, I. Fernandez, T. Ballado, G. Soberon, and R. Palacios. 1982. Reiteration of nitrogen fixation gene sequences in Rhizobium phaseoli. Nature (London) 229:724-726.

31. Rao, J. R., M. Fenton, and B. D. W. Jarvis. 1994. Symbiotic plasmid transfer in Rhizobium leguminosarum biovar trifolii and competition between the inoculant strain ICMP2163 and transconjugant soil bacteria. Soil Biol. Biochem. 26:339-351.

32. Roberts, G. P., W. T. Leps, L. E. Silver, and W. J. Brill. 1980. Use of two-dimensional polyacrylamide gel electrophoresis to identify and classify Rhizobium strains. Appl. Environ. Microbiol. 39:414-422.

33. Romero, D., S. Brom, J. Martínez-Salazar, M. de Lourdes Girard, R. Palacios, and G. Dávila. 1991. Amplification and deletion of a nod-nif region in the symbiotic plasmid of Rhizobium phaseoli. J. Bacteriol. 173:2435-2441.

34. Saitou, R., and M. Nei. 1987. A neighbour-joining method: a new method for reconstructing phylogenetic trees. Mol. Biol. Evol. 44:406-425.

35. Sanger, F., S. Nicklen, and A. R. Coulson. 1977. DNA sequencing with chain-terminating inhibitors. Proc. Natl. Acad. Sci. USA 74:5463-5467.

36. Schofield, P. R., A. H. Gibson, W. F. Dudman, and J. M. Watson. 1987. Evidence for genetic exchange and recombination of Rhizobium symbiotic plasmids in a soil population. Appl. Environ. Microbiol. 53:2942-2947.

37. Scholla, M. H., J. A. Moorefield, and G. H. Elkan. 1990. DNA homology between species of the rhizobia. Syst. Appl. Microbiol. 13:288-294.

38. Segovia, L., J. P. W. Young, and E. Martínez-Romero. 1993. Reclassification of American Rhizobium leguminosanm biovar phaseoli type I strains as Rhizobium etli sp. nov. Int. J. Syst. Bacteriol, 43:374-377.

39. Sessitsch, A., P. K. Jjemba, G. Hardarson, A. D. L. Akkermans, and K. J. Wilson. 1997. Measurement of the competitiveness index of Rhizobium tropici strain CIAT 899 derivatives marked with the gus $A$ gene. Soil Biol. Biochem. 29:1099-1110.

40. Sessitsch, A., G. Hardarson, W. M. de Vos, and K. J. Wilson. Use of marker genes in competition studies of Rhizobium. Submitted for publication.

41. Sessitsch, A., G. Hardarson, A. D. L. Akkermans, and W. M. de Vos. 1997. Characterization of Rhizobium etil and other Rhizobium spp. that nodulate Phaseolus vulgaris L. in an Austrian soil. Mol. Ecol. 6:601-608.

42. Stackebrandt, E., and B. M. Goebel. 1994. Taxonomic note: a place for DNA-DNA reassociation and $16 \mathrm{~S}$ rRNA sequence analysis in the present species definition in bacteriology. Int. J. Syst. Bacteriol. 44:846-849.

43. Swofford, D. L. 1993. PAUP: phylogenetic analysis using parsimony. Version 3.1. The Illinois Natural History Survey, Champaign, Ill.

44. van Berkum, P., D. Beyene, and B. D. Eardly. 1996. Phylogenetic relationships among Rhizobium species nodulating the common bean (Phaseolus vulgaris L.). Int. J. Syst. Bacteriol. 46:240-244.

45. van de Peer, Y., and R. de Wachter. 1994. TREECON for Windows: a software package for the construction and drawing of evolutionary trees for Microsoft Windows environment. Comput. Appl. Biosci. 10:569-570.

46. Vincent, J. M. 1970. A manual for the practical study of root nodule bacteria, p. 73-97. In International biological programme handbook. Blackwell Scientific Publications, Ltd., Oxford, United Kingdom.

47. Weisburg, W. G., S. M. Barns, D. A. Pelletier, and D. J. Lane. 1991. 16S ribosomal DNA amplification for phylogenetic study. J. Bacteriol. 43:374377.

48. Wilson, K. J., A. Sessitsch, J. C. Corbo, K. E. Giller, A. D. L. Akkermans, and R. A. Jefferson. 1995. $\beta$-Glucuronidase (GUS) transposons for ecological and genetic studies of rhizobia and other Gram-negative bacteria. Microbiology 141:1691-1705. 